ACTA THERIOLOGICA

Vol. 29, 17: $219-230,1984$

\title{
Geographical and Intrapopulation Divergence in Clethrionomys glareolus ${ }^{1}$
}

\author{
Michał D. SIKORSKI \& A. D. BERNSHTEIN
}

\begin{abstract}
Sikorski M. D. \& Bernshtein A. D., 1984: Geographical and intrapopulation divergence in Clethrionomys glareolus. Acta theriol., 29, 17: 219-230 [With 5 Tables \& 2 Figs.]

Examination was made of the frequency of 27 non-metric variants of skull and molar structure in Clethrionomys glareolus (Schreber, 1780), originating from four distant and three nearer stations. It was found that out of 351 calculated coefficients of correlation between all pairs of characters, $108 \%$ differed significantly from zero, the proportion for dental characters analyzed separately being $20.6 \%$, but only $4.4 \%$ for skull characters. A significant relation was found between the frequency of six dental characters and age, and between one skull character and the sex of individuals. These characters have been omitted from calculations of the mean measure of divergence (MMD). Using the frequency of the remaining non-metric characters as a basis, calculation was made of the coefficient of the mean measure of divergence for all pairs of distant and nearer populations. Significant differences were found between distant populations in all cases, whereas in the case of populations from the Moscow district significant differences were found only between populations originating from stations situated on either side of a wide highway.

[Mammals Res. Inst., Polish Acad. Sci., 17-230 Białowieża, Poland (MDS) and Inst. Poliomyelitis and Virus Encephalitis, Acad. Medic. Sci, USSR, Moskovskaya oblast, Kievskoye chauss'ee, 27 Kilometr, USSR (ADB)]
\end{abstract}

\section{INTRODUCTION}

Studies on the genetic and habitat factors influencing changes in frequency of non-metric skeletal variants were initiated by Grüneberg (1950, 1952), and later by other scientists (Searle, 1954a; Deol \& Truslove, 1957). The results of these studies, in addition to a description of approximately fifty non-metric characters, revealed the possibility of genetic description of highly inbred strains of mice, on the basis of this type of structural variants of the skeleton. Grewal (1962) used the method proposed by C.A.B. Smith for analysis of the frequency of non-metric characters, as it permits of assessing, by means of the mean measure of divergence index $(M M D)$ differences and their statistical significance between two populations. This method was at first applied to an estimate of divergence in inbred strains, and later by Berry (1968) to estimate divergence in wild populations of house mice and other species of mammals. In recent years non-metric characters have been widely

1 The paper is the result of co-operation between the Mammals Research Institute of the Polish Academy of Sciences and the N. K. Koltzov Institute of Developmental Biology of the USSR Academy of Sciences. 
applied to a variety of comparisons between rodent populations (Hilborn, 1974; Eremina, 1978; Larina, 1978; Hartman, 1980; Larina \& Eremina, 1982). In studies on inter- and intrapopulation differentiation in the bank vole a different degree of divergence was found between populations as various distances, and also intrapopulation differentiation in the frequency of non-metric characters (Krylov \& Yablokov, 1972; Eremina, 1975; Vasilev, 1982; Turutina, 1982).

Estimating by index of divergence was used, inter alia, in population studies to determine the boundaries of the range of populations with a common gene pool, and also in many other genetic and ecological studies (Berry, 1977; Yablokov, 1980). The present paper forms an attempt at estimating the scale of distance of populations which do not belong to a common gene pool. Comparison has been made of the degree of isolation between very distant populations and those occupying a small area, for the bank vole Clethrionomys glareolus (Schreber, 1780).

\section{STUDY AREA, MATERIAL}

The material was collected during the period from 1978-79 in four places in the European part of the Soviet Union. The first sample was obtained in the Moscow district $\left(55^{\circ} 40^{\prime} \mathrm{N}, 37^{\circ} 20^{\prime} \mathrm{E}\right)$. Trapping was carried out on three sites (Fig. 1). On site 1 the trapping line was situated in a spruce plantation with an

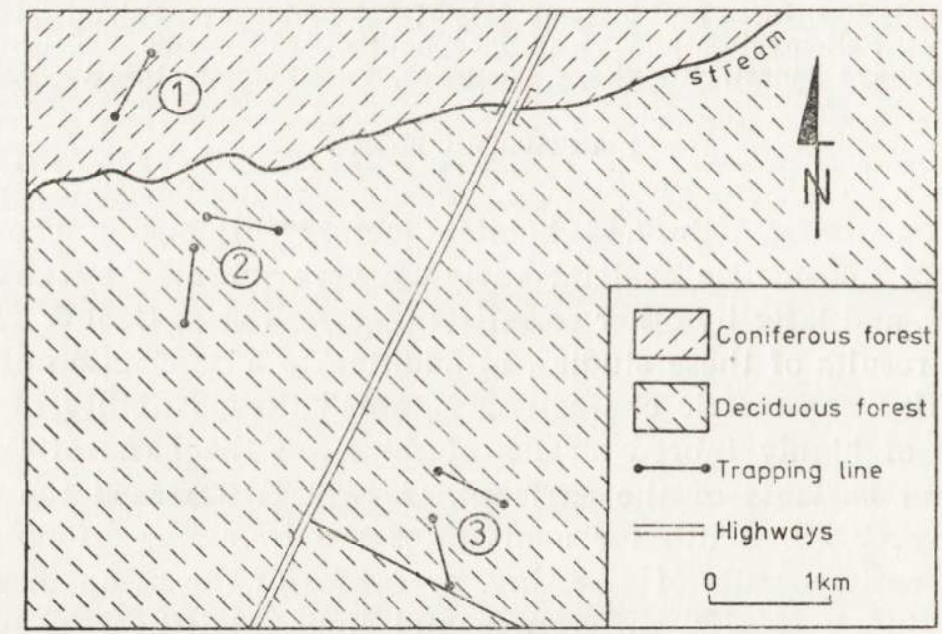

Fig. 1. Plan showing distribution of trapping lines in wooded biotopes in the Moscow district. 1, 2, 3 - numbers showing localization of trapping sites.

admixture of birch and lime, with a thin undergrowth and herb layer. The second sample was obtained in the Tula district $\left(54^{\circ} 45^{\prime} \mathrm{N}, 37^{\circ} 40^{\prime} \mathrm{E}\right)$, which lies in the northern zone of the woodland-steppe region. The study area included wooded land stretching to the north-east of the town, surrounded by cultivated fields and by villages. The trapping lines were situated in a lime-oak tree stand with an admixture of birch, aspen and maple, and a well-developed undergrowth and herb layer. The other areas are situated in the woodland-steppe zone, one 
within the limits of the town of Ufa $\left(54^{\circ} 45^{\prime} \mathrm{N}, 56^{\circ} 00^{\prime} \mathrm{E}\right)$. The trapping lines were situated in an old deciduous tree stand with predominance of lime, oak and ash, with a poorly developed undergrowth and herb layer. The last sample was obtained from the Buzuluk district $\left(52^{\circ} 50^{\prime} \mathrm{N}, 52^{\circ} 10^{\prime} \mathrm{E}\right)$. Trapping was carried out on the bank of the river Samara in a marshy tree stand of elm and lime, with the addition of poplar, maple and oak, and a very well-developed undergrowth and herb layer.

The rodents were caught by the trapping line method. The skulls were first cleaned by insects (Dermestes lardarius) and then in order to obtain a better degree of cleanness, were digested in a papain solution and bleached in $3 \%$ hyirogen peroxide. The age of the individuals was determined by means of the degree of formation and length of root in relation to length of the whole tooth $\mathrm{M}^{2}$ (Koshkina, 1955; Tupikova et al., 1968). The whole sample was divided into the following three age classes on the basis of estimated absolute age of individuals: I - up to 4 months, II $-5-8$ months, III - over 8 months. The frequency of non-metric characters was determined on a total of 383 individuals (Table 1). Equations for statistical calculations, together with corrections, were taken after Sjøvold (1977).

Table 1

Number of individuals from four study populations for which frequency non-metric variants was determined.

\begin{tabular}{lccccc}
\hline & \multicolumn{2}{c}{ Moscow } & Tula & Ufa & Buzuluk \\
& 1978 & 1979 & 1978 & 1978 & 1978 \\
\hline q. & 42 & 55 & 18 & 28 & 31 \\
ơ $^{4}$ & 65 & 68 & 19 & 34 & 23 \\
Total & 107 & 123 & 37 & 62 & 54 \\
\hline
\end{tabular}

\section{LIST OF NON-METRIC CHARACTERS}

MMD values calculated on the basis of frequency of characters determined unilaterally and bilaterally reveal a considerable degree of correlation (Sjøvold, 1977) and consequently frequency of characters was recorded unilaterally, always on the right side of the head. The following characters were taken into consideration.

1. Additional lingual salient angle of $\mathrm{M}^{2}$ present. Lingual salient angle of anterior lohe of $\mathrm{M}^{2}$ semicircular in shape and its posterior margin may be convex in the form of an additional salient angle (Fig. 2).

2. Anterior lobe of $\mathrm{M}^{3}$ joined with $\mathrm{T} 2$.

3. Triangles $\mathrm{T} 2$ and $\mathrm{T} 3$ of $\mathrm{M}^{3}$ joined.

4. Triangles $\mathrm{T} 3$ and $\mathrm{T} 4$ joined.

5. Triangles $T 4$ and $T 5$ of $\mathbf{M}^{3}$ joined. The dentin of the triangles may be completely enclosed by folds of enamel, or these folds may not contact and the dentin of successive triangles is joined.

6. Anterior margin of anterior lobe of $\mathrm{M}^{3}$ concave.

7. Anterior margin of anterior lobe of $\mathrm{M}^{3}$ convex. The anterior margin of the anterior lobe contacting the back of $\mathrm{M}^{2}$ may form, about halfway along its length, a depression directed backwards, or may be curved in an arch to the front (Fig. 1).

8. Second buccal salient angle of $\mathrm{M}^{3}$ longer than the first.

9. Fourth buccal salient angle of $\mathrm{M}^{3}$ present. 
10. Fourth lingual salient angle of $\mathrm{M}^{3}$ present (forma complex).

11. Triangles $\mathrm{T} 1$ and $\mathrm{T} 2$ of $\mathrm{M}_{1}$ joined.

12. Triangles $\mathrm{T} 2$ and $\mathrm{T} 3$ of $\mathrm{M}_{1}$ joined.

13. Triangles $\mathrm{T} 3$ and $\mathrm{T} 4$ of $\mathrm{M}_{1}$ joined.

14. Triangles $\mathrm{T} 4$ and $\mathrm{T} 5$ of $\mathrm{M}_{1}$ joined.

15. Fifth lingual salient angle of $\mathbf{M}_{1}$ strongly developed. The anterior cap from the lingual side may be only slightly indicated, its margin in the anterior direction from the fourth sinus is then almost parallel to the axis of the tooth or may be strongly convex in semicircular form, or an acute angle (Fig. 2).
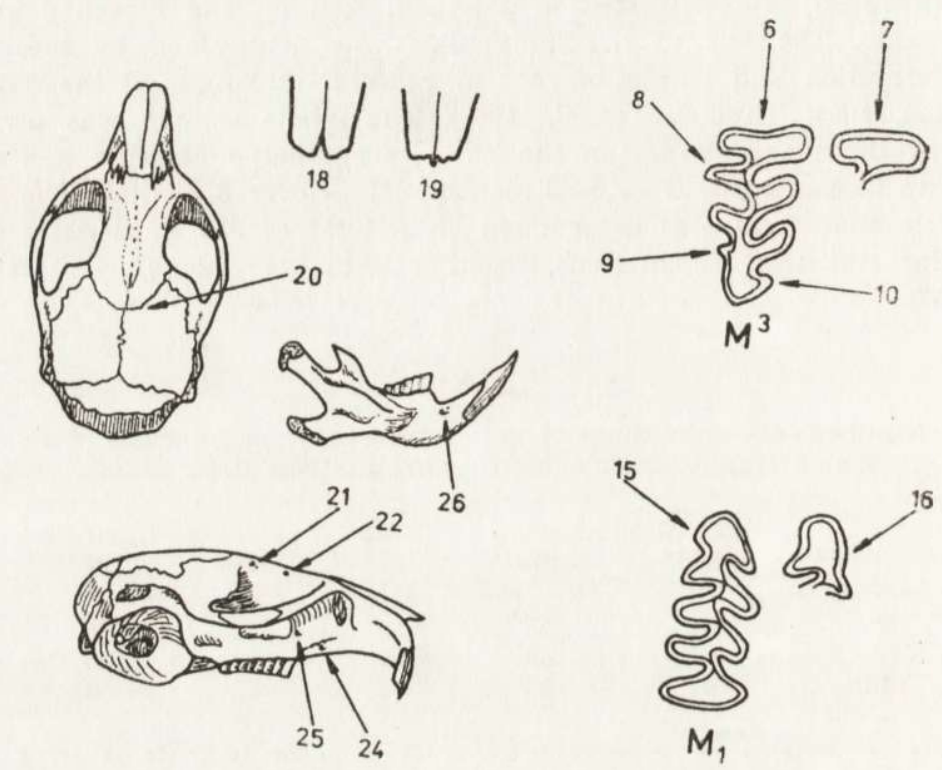

Fig. 2. Non-metric variants of skull and teeth of the bank vole. Numbers of variants as in text.

16. Fourth buccal salient angle of $\mathrm{M}_{1}$ poorly developed. Anterior cap on the buccal side is strongly developed in the majority of individuals, in the form of a fourth salient angle. It is directed backwards and its posterior margin forms an acute angle with the axis of the tooth, may sometimes be only faintly indicated, and its posterior margin forms an almost right angle with the axis of the tooth (Fig. 2).

17.Triangle T4 of $\mathrm{M}_{3}$ absent. This tooth may not have a fourth triangle and then there are only two buccal salient angles (Fig. 2).

18. Posterior margin of nasal bones concave.

19. Posterior margin of nasal bones convex. The posterior margin of the nasal bones forming a suture with the frontal bone may take a variety of forms. The variants are distinguished: nasal bones have a triangular identation with the sharp apex directed forwards, while there is a triangular process, the apex of which is directed backwards, on the posterior margin.

20. Frontoparietal semicircular suture.

21. Frontal foramen double.

22. Accessory frontal foramen present. This is a small opening on the lateral side of the frontal bone near the upper margin of the eye socket, and may also occur as two separate foramina (Berry \& Searle, 1963). Forwards from it near 
the suture with the zygomatic process of the maxillary there may be an accessory frontal foramen.

23. Foramen hypoglossi multiplex. Foramen hypoglossi piercing the parietal bone may be single or double (Deol, 1955). In the bank vole there may also occur three or four separate foramina, and therefore the variant of foramen hypoglossi multiplex has been accepted if there were more than one foramen from the buccal side of the skull.

24. Maxillary foramen I present.

25. Maxillary foramen II present. This is a pair of foramina on the lower buccal side of the maxillary bone. The first of them lies on the prolongation of the dental process of the maxillary bone in front of the teeth row, the second has a more variable position but is usually found laterally on the zygomatic process. Both foramina may be absent, single or double (Berry, 1963).

26. Accessory mental foramen present. The mental foramen is usually single, but an accessory small foramen may sometimes occur by the side of it (Deol, 1955).

27. Supradentary foramen present. This is a small foramen in the upper margin of the mandible in front of the row of teeth.

\section{RESULTS}

\subsection{Correlation between Characters}

The correlation between all pairs of characters was calculated for the sample including individuals from all the populations examined $(n=383$ individuals). Since the square of values for correlation coefficients multiplied by the number of individuals has a distribution agreeing with the chi-square distribution with one degree of freedom, the lowest absolute value of the coefficient at which correlation is significant, may be calculated for the given level of significance. With level of significance $p=0.01$, the critical value above which the coefficient of correlation differs significantly from zero is \pm 0.1316 .

Out of the total number of 351 coefficients of correlation calculated, 38 , i.e. $10.8 \%$, differ significantly from zero. Among these 11 were negative and 27 positive. In the remaining cases the values of the coefficients of correlation are very low, in general lower than 0.1. Dental characters (numbers $1-7$ ) exhibit a far higher number of significant correlations than the skull characters (numbers 18-27). The percentage of coefficients significantly different from zero for dental characters analyzed separately was $20.6 \%$, and for skull characters only $4.4 \%$. Characters nos $2-5$ and $11-14$ (dentin field joined respectively on $M^{3}$ and $\mathrm{M}_{1}$ ) exhibit the greatest number of correlations $(3-8)$. There is distinct correlation between pairs of characters of this type occurring both in each of the above teeth separately, and also between pairs of characters of which one occurs on $\mathrm{M}^{3}$ and the other on $\mathrm{M}_{1}$. This is most clearly visible in respect of character no. 2, which exhibits correlation with all characters of this type, i.e. characters no. $3-5$ and $11-14$. A high number of correlations among the remaining dental characters is 
exhibited by characters no. 9 and 15 , respectively 5 and 6 . In the other characters jointly with skull characters, the number of coefficients significantly different from zero is $0-3$.

Despite the generally very low values for correlation coefficients the number of significant correlations between pairs of characters was greater than anticipated, this being chiefly due to correlations between dental characters. In further analysis the majority of the characters with a considerable number of correlations with other characters have been omitted (see section 4.2), and the remaining characters have been considered as not correlated, which should not affect the results of the final calculations.

\subsection{Homogeneity of Occurrence of Characters Depending on Age and Sex}

In order to discover characters, the frequency of which varies depending on the age of individuals, the chi-square test was used to check the homogeneity of occurrence of characters in age classes. The test was made for the whole sample jointly from all the study areas. On a level of significance of $p=0.01$, with two degrees of freedom, significant differences in frequency in the different age classes were exhibited by characters $2,4,5,9,15$ and 17 . These characters were omitted from further analysis, as their frequency depends on the age of the individuals.

Differences in frequency of characters between sexes was tested by the chi-square test $(p=0.05)$ separately for each sample obtained from the four study areas. In the sample from Tula no characters were found, the frequency of which significantly differed in the two sexes. In the sample from Ufa significant differences were found in the case of characters no. 13, 21 and 22, in the sample from Buzułuk for characters nos. 8 and 22, and in the sample from the Moscow district for characters nos. 24 and 27 . Si ce character no. 22 in all four samples occurred more often in females (frequency of this character in females and males was: Tula - 55.6 and 31.6, Ufa 64.3 and 35.3, Buzuluk 71.0 and 39.1, Moscow 72.9 and 64.2), whereas in samples from Ufa and Buzuluk this difference was statistically significant, therefore as a character connected with sex it has been omitted from further analysis.

In the sample from the Moscow district the differences in frequency of characters in two successive years of trapping were checked by means of the chi-square test. Separate tests were made for each of the three trapping sites. On the level of significance of $p=0.01$ significant difference in frequency between samples from 1978 and 1979 were shown as follows: on site no. 1 character no. 13 , on site no. 2 characters nos. 6 and 25 and on site no. 3 characters $11,13,14$ and 24. Frequency of character no. 13 exhibited a significant difference on trapping sites nos 2 and 3 , frequency being greater on site no. 2 in 1978, and on site no. 3 
in 1979. Since in further analysis the frequencies of characters in successive years were totalled, this character has been omitted as being unstable in time. In other cases significant differences occurred singly and it was considered that this should not affect further calculations.

\subsection{Measure of Divergence between Populations}

After selecting characters, the frequency of which depended on the age and sex of individuals, and for samples from the Moscow district characters with frequency varying in successive trapping years, the frequencies of the remaining characters (Tables 2, 3) were tested

Table 2

Frequency in percentage of non-metric variants for samples from distant populations.

\begin{tabular}{|c|c|c|c|c|}
\hline List of variants & $\begin{array}{c}\text { Moscow } \\
n=47\end{array}$ & $\begin{array}{c}\text { Tula } \\
n=37\end{array}$ & $\begin{array}{c}\text { Ufa } \\
n=62\end{array}$ & $\underset{n=54}{\text { Buzuluk }}$ \\
\hline 1. Acces. LSA of $\mathbf{M}^{2}$ present & 14.9 & 0.0 & 0.0 & 9.3 \\
\hline 3. $\mathrm{T} 2$ and $\mathrm{T} 3$ of $\mathrm{M}^{3}$ joined & 12.8 & 21.6 & 27.4 & 16.7 \\
\hline 6. Anter. margin of $\mathrm{AL}$ of $\mathrm{M}^{3}$ concave & 72.3 & 81.1 & 69.4 & 79.6 \\
\hline 7. Anter. margin of $\mathrm{AL}$ of $\mathrm{M}^{s}$ convex & 2.1 & 5.4 & 1.6 & 9.3 \\
\hline 8. Sec. BSA of $\mathrm{M}^{3}$ long. than the first & 51.1 & 62.2 & 79.0 & 38.9 \\
\hline 10. Fourth LSA of $\mathbf{M}^{3}$ present & 72.3 & 54.1 & 62.9 & 29.6 \\
\hline 11. $\mathrm{T} 1$ and $\mathrm{T} 2$ of $\mathrm{M}_{1}$ joined & 87.2 & 78.4 & 91.9 & 96.3 \\
\hline 12. $\mathrm{T} 2$ and $\mathrm{T} 3$ of $\mathrm{M}_{1}$ joined & 10.6 & 2.7 & 0.0 & 11.1 \\
\hline 13. $\mathrm{T} 3$ and $\mathrm{T} 4$ of $\mathrm{M}_{1}$ joined & 59.6 & 64.9 & 77.4 & 66.7 \\
\hline 14. $\mathrm{T} 4$ and $\mathrm{T} 5$ of $\mathrm{M}_{1}$ joined & 78.7 & 75.7 & 83.9 & 70.4 \\
\hline 16. BSA4 of $\mathrm{M}_{1}$ poorly developed & 2.1 & 5.4 & 4.8 & 7.4 \\
\hline 18. Post. margin of nasals concave & 63.8 & 45.9 & 83.9 & 59.3 \\
\hline 19. Post. margin of nasals convex & 2.1 & 2.7 & 1.6 & 1.9 \\
\hline 20. Frontoparietal sut. semicircular & 19.1 & 16.2 & 12.9 & 18.5 \\
\hline 21. Frontal for. double & 29.8 & 21.6 & 19.4 & 29.8 \\
\hline 23. For. hypoglossi multiplex & 61.7 & 37.8 & 45.2 & 70.4 \\
\hline 24. Max. for. I present & 55.3 & 81.1 & 59.7 & 59.3 \\
\hline 25. Max. for. II present & 55.3 & 62.2 & 75.8 & 81.5 \\
\hline 26. Acces. mental for. present & 10.6 & 2.7 & 9.7 & 7.4 \\
\hline 27. Supra-dentary for. present & 10.6 & 21.6 & 8.1 & 9.3 \\
\hline
\end{tabular}

(chi-square test, $p=0.05$ ), for homogeneity between populations from the areas compared. If significant differences in frequency occurred at least between one pair of tested populations, then this character was taken as not homogeneous. When testing samples from distant sites it was. found that the following characters exhibited frequency which is not homogeneous: $1,8,10,11,12,18,23,24$ and 25 , but for samples from the Moscow district characters nos. 1, 3, 7, 8, 12, 25 and 26. Frequencies of the remaining characters did not exhibit significant differences between the various study areas. Mean measures of divergence between samples were calculated for samples from distant sites jointly for 20 characters (Table 4), but for 19 characters for samples from the Moscow district (Table 5). Tables 4 and 5 contain $M M D$ values 
between all combinations of pairs of populations. In table 4 all $M M D$ values are greater than the double value of S.D. (MMD) and thus point to significant differences between the four study populations. When samples from the Moscow district are compared (Table 5) significant differences were found between sites 1 and 3 , and 2 and 3 , and thus between samples from sites situated each side of the highway. No signi-

Table 3

Frequency in percentage of non-metric variants for samples from three trapping sies in the Moscow district.

\begin{tabular}{|c|c|c|c|}
\hline List of variants & $\begin{array}{l}\text { Site } 1 \\
\mathrm{n}=30\end{array}$ & $\begin{array}{l}\text { Site } 2 \\
\mathrm{n}=115\end{array}$ & $\begin{array}{r}\text { Site } 3 \\
n=85\end{array}$ \\
\hline 1. Acces. LSA of $\mathbf{M}^{2}$ present & 0.0 & 13.0 & 0.0 \\
\hline 3. $\mathrm{T} 2$ and $\mathrm{T} 3$ of $\mathrm{M}^{8}$ joined & 0.0 & 10.4 & 3.5 \\
\hline 6. Anter. margin of $\mathrm{AL}$ of $\mathrm{M}^{3}$ concave & 66.7 & 65.2 & 52.9 \\
\hline 7. Anter. margin of AL of $\mathrm{M}^{8}$ convex & 10.0 & 10.4 & 25.9 \\
\hline 8. Sec. BSA of $\mathrm{M}^{3}$ long. than the first & 76.7 & 59.1 & 43.5 \\
\hline 10. Fourth LSA of $\mathrm{M}^{3}$ present & 60.0 & 58.3 & 48.2 \\
\hline 11. $\mathrm{T} 1$ and $\mathrm{T} 2$ of $\mathrm{M}_{1}$ joined & 90.0 & 84.3 & 74.1 \\
\hline 12. $\mathrm{T} 2$ and $\mathrm{T} 3$ of $\mathrm{M}_{1}$ joined & 0.0 & 7.0 & 0.0 \\
\hline 14. $\mathrm{T} 4$ and $\mathrm{T} 5$ of $\mathrm{M}_{1}$ joined & 66.7 & 75.7 & 64.7 \\
\hline 16. BSA4 of $\mathrm{M}_{1}$ poorly developed & 0.0 & 2.6 & 1.2 \\
\hline 18. Post. margin of nasals concave & 50.0 & 49.6 & 51.8 \\
\hline 19. Post. margin of nasals convex & 16.7 & 9.6 & 3.5 \\
\hline 20. Frontoparietal sut. semicircular & 23.3 & 17.4 & 14.1 \\
\hline 21. Frontal for. double & 33.3 & 31.3 & 31.8 \\
\hline 23. For. hypoglossi multiplex & 53.3 & 54.8 & 43.5 \\
\hline 24. Max. for. I present & 66.7 & 60.0 & 71.8 \\
\hline 25. Max. for. II present & 76.7 & 64.3 & 78.8 \\
\hline 26. Acces. mental for. present & 10.0 & 6.1 & 0.0 \\
\hline 27. Suprá-dentary for. present & 13.3 & 10.4 & 5.9 \\
\hline
\end{tabular}

Table 4

Mean measure of divergence and standard deviation of $M M D$ (given in italics), between distant populations. $M U$ - measure of uniqueness.

\begin{tabular}{lcccc}
\hline & Tula & Ufa & Buzuluk & MU \\
\hline Moscow & 0.0564 & 0.0651 & 0.0526 & 0.1741 \\
& 0.0268 & 0.0279 & 0.0231 & \\
Tula & & 0.0497 & 0.0640 & 0.1701 \\
& & 0.0246 & 0.0279 & \\
Ufa & & & 0.1020 & 0.2168 \\
Buzuluk & & & 0.0286 & 0.2186 \\
\hline
\end{tabular}

ficant difference was found between samples from sites 1 and 2 situated in different biotopes.

Tables 4 and 5 contain values of measure of uniqueness $(M U)$ for each population, calculated as the sum total of mean measures of divergence with which these populations were compared. On the basis of $M U$ values the four samples compared may be divided into two groups, 
one including the populations from Ufa and Buzuluk with higher values, and the second the populations from the Moscow district and from Tula, with lower values of this coefficient. Thus populations from more distant study stations differ to a greater degree. Maximum value $M U$, indicating the greatest difference among the samples from the Moscow district, were found in the sample from trapping site no. 3 .

Table 5

Mean measure of divergence and standard deviation of $M M D$ (given in italics), between individuals from populations in the Moscow district. $M U-$ of uniqueness.

\begin{tabular}{lccc}
\hline & Site 2 & Site 3 & $M U$ \\
\hline Site 1 & 0.0107 & 0.0512 & 0.0619 \\
Site 2 & 0.0166 & 0.0246 & \\
Site 3 & & 0.0616 & 0.0723 \\
\hline
\end{tabular}

\section{DISCUSSION}

In studies on divergence between populations the lists of non-metric characters include, in the majority of papers, mainly variants in the morphological structure of the skull and the skeleton apart from the skull, and only sporadically variations in teeth. In the present paper $63 \%$ is formed by variants of dental differences. As the initial selection of characters showed, dental characters exhibit a far greater degree of correlation - (section 4.1.) and the frequency of six of them proved to be dependent on the individuals' age (section 4.2.). Increase in the frequency of occurrence of forma simplex of $\mathrm{M}^{3}$ together with increasing age of individuals was found in the bank vole by Zejda (1960). It would therefore appear that variants of differences in teeth, despite their easy classification, are less suitable for analysis of frequencies in studies on divergence between populations.

The significant differences between all the sample compared from distant populations point to genetic differentiation of populations. This is not surprising if it is remembered that the samples were obtained from populations separated by distances of about two hundred to over a thousand kilometers. Apart from geographical isolation connected with distance and climatic differences due to the geographical position of the study areas, such results may also be affected by differences in the biotopes in which the bank voles were caught. Similar geographical differentiation in bank vole populations in other parts of the range of this species were found by such scientists as Eremina (1975) and Vasilev (1982). It is also known that populations of bank voles from the Tula 
and Ufa districts differ significantly in respect of body weight and relative weight of internal organs (Bernshtein et al., 1971).

The most evident factors capable of influencing divergence in bank voles occupying wooded biotopes in the Moscow district are the types of tree stand and the situation of the trapping lines. Sites 1 and 2 (Fig. 1) were situated at short distances from each other, but in different types of tree stand, and thus differed fundamentally in respect of the food supply. The food supply available in the spruce plantation in which site no. 1 was situated is far poorer than that of the deciduous forest where sites 2 and 3 were situated. It is known from studies on the causes of epigenetic polymorphism in inbred strains of mice (Searle, 1954b; Deol \& Truslove, 1957) that frequency of occurrence of non-metric characters may alter, e.g. as the result of poor diet of pregnant females. No significant difference in $M M D$ was found between sites 1 and 2 . Under natural conditions a poorer food supply might contribute to lower productivity and survival, revealed by lower density, estimated by means of the coefficient of trappability on site no. 1 in comparison with sites nos. 2 and 3 , but did not cause differences in MMD. Similarly Berry (1963) did not find distinct und unequivocal differences between house mice occupying stacks of different species of cereals providing a great diversity of diet.

Distinct differences between individuals from different biotopes were found, on the basis of analysis of non-metric characters (non-coefficient method) in the bank vole by Turutina (1982). Despite differences in frequency of different characters between samples from sites nos. 1 and 2, the coefficient method of analysis based on $M M D$ did not reveal significant differences between samples from different biotopes. Significant differences were, however, found between voles from site no. 3 and the other two sites, i.e. between samples from populations originating from trapping sites about 3-4 kilometers apart and separated by a wide highway. On account of the highest value for measure of uniqueness, the sample from site no. 3 differs most from the other samples (Table 5). This difference is certainly due to the separation of bank vole populations by an artificial barrier in the form of the highway, which constitutes a considerable barrier to the spread of small rodents, and in particular limits the migration of forest species in places where the highway and grass verges bisect forest biotopes (Oxley et al., 1974; Wilkins, 1982).

\section{REFERENCES}

1. Bernshtein A. D., Ryltseva E. V., Zubri G. L., Snokin V. D. \& Myasnikov Yu. A., 1971: Morpho-physiological characteristics of two populations of Clethrionomys glareolus in natural foci of hemorrhagic fever with renal syndrome. Tr. Inst. poliomielita i virusnyh èncefalitov AMN SSSR, 19: 301-313. [In Russian with Eng]ısh summary]. 
2. Berry R. J., 1963: Epigenetic polymorphism in wild populations of Mus musculus. Genet. Res., 4: 193-220.

3. Berry R. J., 1968: The biology of non-metrical variation in mice and men. [In: Brothwell D. R. (ed.), "The skeletal biology of earlier human populations"]. 103-133. London.

4. Berry R. J., 1977: Inheritance and natural history. L. Collins: $1-350$.

5. Deol M. S. \& Truslove G. M., 1957: Genetical studies on the skeleton of the mouse. XX. Maternal physiology on variation in the skeleton of C57BL mice. J. Genet., 55: 288-312.

6. Eremina I. V., 1975: Geografija i èvoljucija fenov risunka ževatelnoj poverhnosti pervogo nižnego i tretego verhnego moljarov u ryžej polevki (Evropejskaja čast SSSR). [In: "Fiziologičeskaja i populjacionnaja èkologija životnyh"]. Izd. Sarat. Univ., Saratov, 3, 5: 82-95. [In Russian].

7. Eremina I. V., 1978: Metodika vydelenija fenov ževatelnoj poverhnosti korennyh zubov u polevok. [In: "Fiziologiðeskaja i populjacionnaja èkologija zivotnyh"]. Izd. Sarat. Univ., Saratov, 5, 7: 60-68. [In Russian].

8. Grewal M. S., 1962: The rate of genetic divergence of sublines in the C57BL strain of mice. Genet. Res. Camb., 3: 226-237.

9. Grüneberg H., 1950: Genetical studies on the skeleton of the mouse. I. Minor variation of the vertebral column. J. Genet., 50: 112-141.

10. Grüneberg H., 1952: Genetical studies on the skeleton of the mouse. IV. Quasicontinuous variations. J. Genet., 51: 95-114.

11. Hartman S. E., 1980: Geographic variation analysis of Dipodomys ordii using non-metric cranial traits. J. Mamm., 61: 436-448.

12. Hibbard C. W., 1950: Mammals of the rexroad formation from Fox Canyon, Kansas. Centr. Mus. Palent. Univers., Michigan, 8: 113-192.

13. Hilborn R., 1974: Notes and comments on inheritance of skeletal polymorphism in Microtus californicus. Heredity, 33: 87-121.

14. Koshkina T. V., 1955: Metod opredelenia vozrasta ryžih polevok i opyt ego primenenija. Zool. Z., 34: 631-639. [In Russian].

15. Krylov D. G. \& Yablokov A. V., 1972: Epigenetičeskij polimorfizm v stroenii Łerepa ryžej polevki (Clethrionomys glareolus). Zool. Z., 51: 576-583. [In Russian].

16. Larina N. I., 1978: Obšcie problemy i metody fenetiðeskih issledovanij. In Fiziologið̌eskaja i populjacionnaja èkologija životnyh. Izd. Sarat. Univ., Saratov, 5, 7: 12-22. [In Russian].

17. Larina N. I. \& Eremina I. V., 1982: Nekotorye aspekty izučenija feno- i genofonda vida i vnutrivivyh gruppirovok. [In: "Fenetika populjacij"]. Izd. Nauka: 56-69. Moskva. [In Russian].

18. Oxley D. J., Fenton M. B. \& Carmody G. R., 1974: The effects of roads on populations of small mammals. J. Applied Ecol., 11: 51-59.

19. Searle A. G., 1954a: Genetical studies on the skeleton of the mouse. IX. Causes of skeletal variation within pure lines. J. Genet., 52: 68-102.

20. Searle A. G., 1954b: Genetical studies on the skeleton of the mouse. XI. The influence of diet within pure lines. J. Genet., 52: 413-424.

21. Sjøvold T., 1977: Non-metrical divergence between skeletal populations. Ossa, 4: Supplement 1: $1-133$.

22. Tupikova N. V., Sidorova G. A. \& Konovalova E. A., 1968: A method of age determination in Clethrionomys. Acta theriol., 13: 99-115.

23. Turutina L. V., 1982. Izučenie prostranstvenno-genetićeskoj struktury dvuh vidov pozvonočnyh životnyh (Lacerta agilis L., Clethrionomys glareolus Schreb.) feneticeskim metodom. [In: "Fenetika populjacij”]. Izd. Nauka: 174-187. Moskva. [In Russian]. 
24. Vasilev A. G., 1982: Opyt èkologo-fenetičeskogo analiza urovnja differenciacii populjacionnyh gruppirovok $\mathbf{s}$ raznoj stepenju prostranstvennoj izoljacii. [In: "Fenetika populjacij"]. Izd. Nauka: 15-24. Moskva. [In Russian].

25. Wilkins K. T., 1982: Highways as barriers to rodent dispersal. Southwest. Naturalist, 27: 459-460.

26. Zejda J., 1960: The influence of age on the formation of third upper molar in the bank vole Clethrionomys glareolus (Schreber, 1780) (Mamm.: Rodentia). Zool. Listy, 9: 159-166.

27. Yablokov A. V., 1980: Fenetika: Evoljucija, populjacija, priznak. Izd. Nauka: 1-136. Moskva. [In Russian].

Accepted, May 5, 1984.

\section{Michał SIKORSKI \& A. D. BERNSHTEIN}

\section{GEOGRAFICZNA I WEWNĄTRZPOPULACYJNA DYWERGENCJA CLETHRIONOMYS GLAREOLUS}

\section{Streszczenie}

Analizowano frekwencję 27 niemetrycznych wariantów budowy czaszki i zębów trzonowych nornicy rudej. Material pochodzil z czterech izolowanych geograficznie stanowisk oraz $\mathrm{z}$ trzech powierzchni odłownych usytuowanych w różnych biotopach leśnych w niewielkiej odleglości (Ryc. 1). Stwierdzono, że na 351 obliczonych wspbłczynników korelacji pomiędzy wszystkimi parami cech $10,8 \%$ istotnie różni się od zera, przy czym udział ten dla cech zębowych, analizowanych oddzielnie, wynosi $20,6 \%$, a dla cech czaszkowych tylko $4,4 \%$. Stwierdzono istotna zależność frekwencji sześciu zębowych cech od wieku i jednej cechy czaszkowej od płei osobników. Cechy te zostały pominięte przy obliczeniach średniej miary dywergencji $(M M D)$. Na podstawie frekwencji pozostalych cech niemetrycznych obliczono współczynnik $M M D$ dla wszystkich par odległych i blisko położonych populacji. Pomiędzy odleglymi populacjami we wszystkich przypadkach otrzymano istotne różnice. Natomiast $w$ przypadku populacji ze stanowisk położonych w niewielkiej odległości istotne różnice stwierdzono tylko pomiędzy próbami z populacji pochodzących ze stanowisk po obu stronach szosy. 